\title{
Some Misconceptions about Infantile Autism
}

\author{
E. B. Peltz, B.A. Hons. (Rand)*
}

\begin{abstract}
"I can't believe that!" said Alice.
"Can't you?" the Queen said in a pitying tone. "Try again: draw a long breath and shut your eyes."

Alice laughed. "There's no use trying," she said: "one can't believe impossible things."

"I dare say you haven"t had much practice" said the Queen. "When I was your age I always did it for half an hour a day. Why sometimes l've believed as many as six impossible things before breakfast.":
\end{abstract}

For therapists to be as level-headed as Alice. it might help to know which impossible beliefs about infantile autism have been dissipated recently.

Theories of Autism. The first large follow-up study of autistic children put great empliasis on the prognostic importance of speech at five years of age (Kanner and Eisenberg ${ }^{16}$ ). In this study involving thirty-one subjects it appeared that all but one who were not speaking at the age of five were found to be feeble-minded, and/or grossly disturbed at adolescence or as adults. Somehow this statistic has remained with us, leading either to therapeutic pessimism and premature institutionalization or providing an excuse for halfhearted therapy.

This follow-up also disclosed that psychotherapy and other psychiatric treatments had no effect. More recently a large follow-up study by Rutter, Greenfeld and Lockyer ${ }^{30}$ found that of thirty-one, five-year-old non-speakers, seven learned to speak after the age of five years. In all cases these children were receiving good schooling or speech therapy. The use of operant conditioning with autistic children of five to thirteen years has shown even more optimistic results, e.g. Lovaas ${ }^{18}$ taught speech to a nine-year-old girl, Pamela, who had previously undergone four years of unsuccessful psychoanalysis. Pamela even learned to amuse herself with spontaneous activity when alone, e.g. drawing (Lovaas et $\mathrm{al}^{19}$ ). Jenson and Womack $^{14}$ were using milieu therapy, before turning to operant conditioning to teach speech to a seven-year-old boy. Hewett ${ }^{10}$ taught a previously intractable thirteen-year-old autistic boy to read, so that he could eventually communicate by writing. Can we afford to reserve judgment on conditioning until follow-ups are reported?

* Now at The Institute of Psychiatry, London.

Journal of the South African Logopedic Society, Vol. 16, No. 1, Dec. 1969 
In his first description of the autistic syndrome, Kanner ${ }^{15}$ suggested that the primary defect was a disturbance in affective contact. On the other hand, Rutter"s felt that autism is an impairment of länguage function. Recently, many writers have claimed that it is caused by a cognitive or perceptual, rather than an affective difficulty. Evidence for this thesis will be put forward later.

Rutter et al. ${ }^{3 r}$ showed that the intelligence quotient of the autistic child is just as stable as in any other child and is a remarkably good predictor of the child's later intellectual, social and behavioural adjustment. Social withdrawal, however, was found to diminish gradually with natural development, while children with the best outcomes in adolescence showed little change in intelligence quotient. In this study there were several children who remained completely without speech and yet had lost all evidence of social withdrawal. There are therapists who claim that although they have not succeeded over many years in teaching the autistic child speech, nevertheless they have reduced his autism. This is a wishful delusion. To evaluate therapy it is essential to know which symptoms are likely to remit spontaneously. Rutter ${ }^{20}$ reported that:

\footnotetext{
it is striking that social withdrawal more than most symptoms tends to lessen considerably as the autistic child grows older. (P. 10)
}

A major misconception which has been attacked is the interpretation of the autistic child's attraction to spinning objects. The autistic child can spend hours watching objects spin or twirling himself. Hand flapping, which may be a related symptom, can take many forms, e.g. wiggling of the fingers, flicking at surfaces or oscillating of the hand. Ornitz and $\mathrm{Ritvo}^{21}$ considered hand flapping in response to a spinning top as diagnostic of autism. However, many autistic children later learn to suppress these behaviours. Ornitz and Ritvo ${ }^{22}$ mentioned that the vestibular system of the child may be pathologically involved.

Careful and detailed studies of the behaviour of autistic children (hand flapping in particular) have been carried out. Sorosky et al. ${ }^{33}$ showed that the average amounts of autistic behaviours over prolonged periods remain consistent. Environmental variables were shown to have little or no effect on these behaviours. Ritvo et al. ${ }^{27}$ felt that such findings could best be explained as resulting from an ongoing neuropathological process within the central nervous system. They showed that:

(a) there is a statistically significant consistency in the frequencies of these behaviours among autistic children and within the same child.

(b) once initiated, these behaviours are sustained at the same frequency, unaffected by fatigue and presumed changes in the ideational or affectual state. 
These motility patterns appeared in autistic children with varying degrees of severity of the disorder. Ritvo et al. ${ }^{2 z}$ postulated that the transient hand flapping and posturing seen in the startle reaction of the normal infant is never inhibited in the autistic child. They argued that there is an imbalance between excitation and inhibition mechanisms in the child. (Another rational hypothesis is that these mannerisms have a self-stimulatory function.) Ritvo et $\mathrm{al}^{2 z}$ strongly disagreed with the idea that withdrawal into fantasy could cause these behaviours, arguing that:

.. all children regularly defecate and urinate and have fantasies about these behaviours. However, no-one would argue for the assumption that such fantasies actually produce the excrements in question. (P. 346)

In view of the accumulating evidence towards a neurological basis for this behaviour, it would seem absurd to interpret flapping as a defence mechanism. I have seen one unfortunate autistic boy whose attraction to spinning objects was interpreted as a desire for the breast and for a long time he was allowed to unravel film and tape recorder reels undisturbed. This did not seem to satiate his longing. Similar interpretations suggesting acting out therapy are quite detrimental, if one considers the consistent reinforcement of antisocial behaviour which this entails.

Another feature of infantile autism which has been over-burdened with naive interpretations is the autistic child's tendency to pronomial reversal. Bettelheim ${ }^{1}$ claimed that autistic children will never echo $I$ although they will echo other personal pronouns. This he related to their lack of a self-concept. Rutter ${ }^{2 y}$ reported a study to test this inference, which found that when the position of the pronoun in the sentence was controlled, and obviously this is essential, autistic children did echo $I$ as often as they echoed any other pronoun. The fact that $I$ is rarely echoed under normal circumstances is simply a function of the fact that $l$ usually comes at the beginning of a sentence, the part that is not commonly echoed.

Added evidence against a psycho-analytic interpretation of pronomial reversal is pointed out by Fay $^{\mathbf{b}}$, i.e. that autistic children also fail to edit the demonstrative pronouns this and these to that and those. Fay's autistic subject showed many more echoisms and errors in response to questions in which the carrier phrase was show me the than questions in which the phrase was point to the ..... The writer has confirmed this feature of the comprehension of the autistic child on another child. Surely linguistic or conceptual explanations are far more parsimonious than those in terms of aggression and rejection towards the interlocutor.

Bettelheim ${ }^{1}$ has also claimed that the autistic child's lack of high level performance is the result of disinclination, which masks an

Journal of the South African Logopedic Society, Vol. 16, No. 1, Dec. 1969 
average or above-average level of intelligence. Hingtgen and Churchilli1 showed that when motivational levels were elevated and when previously learned behaviours were being emitted consistently, autistic children still experienced extreme difficulty in learning low-level tasks.

Undoubtedly it is true that most autistic children are retarded in language development and that many never overcome these conceptual difficulties thus remaining without abstract language $\left(\operatorname{Rutter}^{29}\right)$. In view of these facts it is astonishing to note the tendency to interpret the autistic child's action to him during therapy. Brawley et al. ${ }^{2}$ have shown that remarks like You don't have to hit yourself, Steve. Do you feel angry with yourself? Was that (task) too hard?, actually increase the frequency of the undesirable behaviour. Remarks that $I$ have heard, e.g. Are you feeling a little mixed-up today?, are probably even more unintelligible to the child.

The parents of the autistic child are reputedly detached, refrigerated and obsessive, but some writers have not found this a consistent trait $\left(\right.$ Rutter $\left.^{29}\right)$. Even if this is granted for the moment certain difficulties arise:

(a) mothers may become detached and ambivalent in response to their disturbed child.

(b) autistic children rarely have a history of the deprived circumstances of the institutionalised child.

(c) it would have to be a very severe parental abnormality indeed to cause so gross a disorder as infantile autism in so short a time. It is always dangerous to argue from correlation to cause, and until some factual surveys appear, we should avoid the all too frequent judgments of the autistic child's parents.

The early descriptions of autistic children also found that their parents were from the academic and professional communities. However, the broader clinical experience of the next two decades has shown that these children come from every socio-economic class. Ornitz and Ritvo ${ }^{21}$ reported that:

While some of the parents are reported to be cold, isolated or refrigerated individuals, others have proven to be warm, loving and quile capable of raising normally affectionate siblings of their autistic child. A condition of family disruption and emotional turmoil may surround the infancy or childhood of autistic children or the disease process may develop in a normal emotional climate. (P. 78)

Autism as a cognitive dysfunction. Rimland ${ }^{23}$ claimed that the autistic child is grossly impaired in a function basic to all cognition; the ability to relate new stimuli to remembered experience. New sensation can only be related to sharply limited fragments of memory, and the child therefore cannot derive meaning from his 
experience. Consequently he cannot understand rclationships, nor think in terms of concepts, symbols, analogies or abstractions. He cannot integrate his sensations into a comprehensible whole; his perception of the world is vague and obscure. However, on tasks in which the input does not have to be re-organised, the autistic child can show high-level performance, e.g. form boards.

Strong evidence for such a hypothesis is provided by the autistic child's pattern of cognitive abilitics $\left(\right.$ Rutter $\left.^{2 s}\right)$. Characteristically the child's immediate memory is good, but on tests of verbal concepts, abstraction or symbolization he is poor. This also applies to tests which do not require the child to speak. There is no evidence that the mutism is in any way elective. Rutter ${ }^{2 s}$ noticed in the Maudsley series that the peaks of intelligence of the autistic child were found almost exclusively on the block design and object assembly tests of the Wechsler Intelligence Scale for Children, probably because these tests requirc the least in the way of comprehension of instructions.

We have already discussed the facts from follow-up studies which support a language dysfunction hypothesis, viz. that the language difficulties must be considered as a primary phenomenon, not as a feature secondary to social withdrawal. Rather, it is the comprehension defects which might lead to withdrawal. The typical lack of response to sounds, the frequency with which the autistic child is considered to be deaf and the difficulties with spoken instruction suggest a rclationship between autism and receptive aphasia. Rutter ${ }^{29}$ mentioned that the audiometric responses of autistic children and of children with receptive aphasia are the same. Possibly the autistic child's problems are not restricted to the auditory modality. While the aphasic's non-verbal responses are superior to those which requirc verbal input or output, the autistic child shows less scatter. Davis ${ }^{4}$ felt that the language deficits in autistic children were directly related to the pervasive concreteness of all their behaviour.

In a scries of experiments, O'Connor and Hermelin have been unravelling the nature of the conceptual dysfunction. They have repeatedly highlighted the difficulty autistic children have in responding to structure in their environments.

These dysfunctions, as shown in recall tests, included:

(a) Syntactic structure: Hermelin ${ }^{\$}$ demonstrated that autistic children recalled sentences and random arrangements of words equally well, while normal and sub-normal controls could only match their recall of sentences. The autistic children tended to remember the last part of any message whether sense or nonsense, while the controls regrouped the words, recalling the most meaningful parts. This throws light on a feature of autism, viz. echolalia.

Journal of the South African Logopedic Society, Vol. 16, No. 1, Dec. 1969 
(b) Semantic structure: When a scries of words from two conceptual categories were presented (e.g. blue, horse, pig, red, dog. yellow), the normals and subnornals showed significantly more reclustering into concepts and thus higher recall than the autistics.

(c) Phonetic stress: Under one condition sentences were presented with stress on the key words, under the second condition stress was on cornecting words. It was found that autistics recalled the stressed words under both conditions, while normals recalled the key words.

Further experiments, with binary sequences, showed that autistic children have difficulty in detecting structure in any modality. When errors were analysed, the normals were found to have detected the dominant features of the sequences, while the crrors of the autistics were random.

This confirmed earlier work by O'Connor and Hermelin ${ }^{20}$ which showed that in learning tasks, autistic children, particularly those without speech, had difficulty in processing information given to them, while subnormal controls did not exhibit these difficulties. Hermelin emphasised the autistic child's relative inability to vary his response according to the stimulus.

\section{Reisiforcement therapy.}

Traditional psychodynamic mothods of therapy, in all their diversity, have failed to demonstrate any reasonable degree of efficacy with psychotic children... On the other hand the rapidly growing body of literature reporting results of behaviour modification methods attests to the potential power of this 'new' therapy. (Leff," ${ }^{17}$ P. 397).

Together with this new approach has come a realization of the importance of speech therapy in the remedial programme for the autistic child. Savage ${ }^{31}$ stated that intensification of normal speech stimulation methods produces poor results and operant conditioning is favoured by her as the most satisfactory behavioural approach.

Often, papers from practitioners of psychodynamic therapics explicitly incorporate basic tenets of reinforcement theory in their therapies. Weiland and Rudnick ${ }^{3 i}$ made an eight-year-old autistic boy's receipt of his favourite toy contingent upon his verbalization of the word ball, widening the child's vocabulary until he was eventually able to sing songs. Dubnoff ${ }^{5}$ successfully treated an autistic boy and reported:

$\mathrm{He}$ is expected to verbalize his demands before they are gratified. The demands and expectations are commensurate with what a child is able to produce at a given time and only appropriate behaviour is gratified. (P. 386)

Such therapy is a long way from an all-accepting permissive and indiscriminately rewarding psycho-analytic approach, and probably 
the best therapy will evolve from collaboration. Nevertheless Leff ${ }^{15}$ cautioned that:

It is in practices such as these that many therapists, either wittingly or unwittingly, often make effective use of the basic principles of opcrant learning. The cvidence suggests that therapeutic potency is a direct function of the degree to which these principles are systentiatically applied. (P. 403)

Perhaps the simplest hypothetical explanation for the unique success of behavicur modification techniques is that the autistic child is unable to learn under ordinary circumstances, (probably the result of some form of cognitive dysfunction). Unfortunately, however, even more misconceptions than those attached to autism have shrouded the potential of reinforcement therapy.

Bettelheim's' picture of an adult forcing responses from a robotlike child during conditioning is shared by laymen and dogmatic therapists alike. Rimland ${ }^{24}$ confesses that when writing his book he was similarly prejudiced. However, he has since become a champion of operant conditioning and the Lovaas school.

Hingtgen and Churchill ${ }^{11}$ mentioned that sessions were characterized by a happy smiling child performing consistently. While training a thirteen-year-old autistic boy to read. Hewett ${ }^{10}$ noted that his subject's interest in his education steadily grew despite gradual decreases in reinforcement. The child showed enjoyment of his work by laughing and vocalizing. He also frequently initiated new learning tasks by bringing the teacher pictures whose symbolic designation he was eager to master. The consistency and clarity of the operant situation allows even the autistic child an experience of mastery.

The therapist who is thoroughly conversant with the reinforcement technique can broaden the operant approach greatly, e.g. Schell et al. ${ }^{32}$ encouraged a game in which Kipper, their autistic subject, returned a non-preferred cereal reinforcer while the therapist said no, no. Then the therapist said candy, yes while giving the preferred candy. After twelve trials, Kipper was saying no, no when given the cereal and a few times said kiki when the clinician asked what he wanted. Other play activities included tickling and cuddling games. which caused peals of laughter. Kipper was encouraged to say $u p^{\prime}$ or down for being lifted into the air or slid down the therapist's knees. These verbal responses were shown to be dependent on their rewarding consequences. (More formal trainingi was also used.)

A criticism of conditioning is that it is situation-specific, i.e. it does not generalize. Hingtgen and Trost ${ }^{1: 4}$ found that after training autistic children to initiate contact and vocal bchaviour with each other in an experimental situation. these new behaviours were observed to 
increase in the ward setting as well as in the home. Hewett ${ }^{10}$ and Jenson and Womack ${ }^{1 \cdot k}$ reported spontaneous speech developing once transfer out of the experimental situation was effected.

An essential reature of reinforcement therapy is the training of the parents in techniques of conditioning. Many parents have thus been cnabled to take over the training of their autistic child - usually with great success, (e.g. Wolf et al.,"it Risley and Wolf ${ }^{25}$ ). This allows the autistic child to be reintegrated into the family and to enter into natural communities of reinforcement.

Many atavistic behaviours have proved amenable to negative reinforcement (most often time out from positive reinforcement). Tantrums have repeatedly been found to be maintained by adult attentiveness to them. Often it is only when these behaviours are eliminated that teaching programs can begin. In this area we also find many therapists indulging a lay protest reaction against punishment tcchniques, but remember the far greater pain that we subject a child to without hesitation, when it is necessary to remove his tonsils or appendix. Helen Keller was lucky her teacher did not insist on using only hugs and kisses. If she had, Helen Keller would have ended up as a living vegetable. In practice, however, the reinforcement programme is heavily loaded with smiles, cuddles and sweets. Punishment (except time out from positive reinforcement) is avoided as it involves many uncontrolled side effects.

A great advantage of operant conditioning is the speed with which large improvements can be obtained. Hingtgen et al ${ }^{12}$ taught two mute autistic children, over five years of age, who had not responded to all other therapy, to do the following, within three weeks:

(a) use of the body - including imitation of blowing, crossing feet, chewing, etc.

(b) use of objects - including imitated line drawing, folding paper, cutting with scissors, brushing teeth, etc.

(c) vocal responses - seventeen sounds and eleven words were learned by the five-and-a-half year old girl, eighteen sounds and eighteen words by the six-and-a-half year old boy.

This efficiency has never been approached by other therapies.

In order to evaluate experiments of operant conditioning, a special research design is used in which successive measures of the same subject's behaviour are taken. The subject is his own control, in that his base-rate behaviour, recorded prior to therapy, is compared with his behaviour after the experimental manipulation. Temporary discontinuance of the modification procedure (usually the reinforcement) 
is used typically to verify the effects of this procedure. Such cxperimental designs can provide immediate and conclusive demonstrations of efficacy and are far superior to the anecdotal reports from other scheols.

To sid the autistic child, the rainforcement therapist breaks the tasks into infinitesimally small steps, each of which the child can master. However, it is essential to remember that these ingenious programmes are closely related to the reinforcement technique. I have seen a therapist. using the method of an opərant experimenter, without using reinforcement. Such practices are rather dubious considering that almost every article on oparant conditioning is at pains to demonstrate that the reinforcement is the only operative variable.

In the field of infantile autism. the mutual interests of the speech therapist and the psychologist can best be served by close co-operation. The structuring techniques derived from speech therapy with the aphasic child can be applied fruitfully within the conditioning situation. Davis ${ }^{*}$ suggests that one should control the stimulus modality by blocking others that might interfere, e.g. by covering the child's eyes and talking directly into his car. Further, the complexity of the task should be controlled by regulating the number of objects present. e.g. saying one word which the subject must associate with the only object in a clear visual field or a clearly defined movement.

Opcrant training derives its success from the fact that not only are specific behaviours taught, but the child learns how to focus and dircet his attention. A promising development is the recent tendency of behaviour therapists to teach learning sets or strategies to autistic children. Rislcy and Wolf'i; expanded their autistic subjects' vocabulary to phrases and sentences. They were then taught to generalize the grammatical form with appropriate substitutions, which could be called generative speech. There is little limit to the breadth of activities which can be taught through reinforcement.

Savage ${ }^{31}$ wrote:

Many people disagrec with operant conditioning on the rather nebulous grounds of 'inhumanity'. How much less humane is it to deny a child an opportunity to acquire the tools of communication when the alternative is probably long-term care in a psychiatric hospital? Pcople have objected to the method, suggesting that it does not teach language, but produces robot-like speech. In a mute autistic child, words acquired through operant conditioning form the basis of a language pattern. Without this basis, a child will never learn language skills as a means of communication. With $i t$, there is a chance that he might. (P. 87)

Note: Detailed descriptions of speech therapy using operant conditioning can be found in Lovaas ${ }^{19}$, Hewett ${ }^{11}$, Risley and Wolf ${ }^{21}$; Stark et al., ${ }^{34}$ and Brawley et al.?

Journal of the South African Logopedic Society, Vol. 16, No. 1, Dec. 1969 


\section{Summary}

Recent studies throw light on certain widespread misconceptions about infantile autism and cffer rational alteratives:

(a) Autism should not be considered a disturbance in affective contact but a cognitive and perceptual difficulty. This difficulty, rather than social withdrawal, is the central feature of the disorder. Linguistic and problem solving studies tend to confirm this probability.

(b) Pre-occupation with hand flapping and spinning objects in autistic children does not require interpretation, as recent neurological studies indicate the strong probability of a neurological basis for this tendency.

(c) A highly permissive approach is not likely to help the autistic child and may intensify atavistic behaviours. To hold parents of autistic children culpable is unjustified. Progress in therapy and in the home is probably related to a systematic use of reinforcement.

(d) The absence of speech by the age of five years no longer means a hopcless prognosis, as operant conditioning allows speech to be learned after this age.

Desling with autism as a cognitive dysfunction, Rimland"3 emphasises the child's inability to comprehend his environment and to integrate his sensations, while Rutter": shows the similarity between autism and receptive aphasia. He claims that social withdrawal is secondary to language difficulties in autism. For this reason and because the autistic child seems unable to learn under ordinary circumstances, it seems that reinforcement therapy practised within the framework of speech therapy would show the best results. Operant conditioning has been unjustly attacked on many accounts, but the hopeful prognosis and breadth of applicability it offers should be a spur towards dissipation of these misconceptions.

\section{Opsomming}

Onlangse studies werp lig op sekere algemene wanopvattings oor infantiele outisme en bied rasionele alternatiewe:

(a) Outisme moet nie beskou word as 'n versteuring in affektiewe kontak nie, maar wel as 'n kognitiewe en perseptuele afwyking. Laasgenoemde is dan die sentrale kenmerk van die versteuring en nie soseer sosiale onttrekking nie. Linguistiese- en probleemoplossingstudies ondersteun hierdie moontlikheid.

(b) Die bcheptheid van die outistiese kind met handgeswaai en draaiende voorwerpe benodig nie interpretasie nie. Onlangse neuro- 
logiese studies toon in sterk moontlikheid van 'n neurologiese basis vir hicrdie neiging.

(c) 'n Baie toelaatbare benadering word nie aanbeveel nie aangesien dit eerder atovistiese gedrag versterk. On ouers aanspreeklik te hou vir die kind se probleem is onregverdig en ongegrond. Vooruitgang in terapie en ook tuis is blykbaar verwant aan die sistematiese gebruik van versterking.

(d) Die afwesigheid van spraak by 'n ouderdom van vyf jaar beteken nie meer "n hopelose prognose nie - operonte kondisicnering maak voorsiening vir spraakaanleer selfs ná hierdie ouderdom.

By 'n beskouing van outisme as 'n kognitiewe disfunksie beklemtoon Rimland ${ }^{2:}$ die kind se onvermoë on sy ongewing te begryp en om sy sensasies te integreer. Rutter ${ }^{30}$ wys op die ooreenkoms tussen cutisme en reseptiewe afasie en beweer dat dic sosiale ontrekking sekondêr is tot die taalprobleme. Hierdie is een rede waarom kondisioneringsterapic, beofen binne die raamwerk van spraakterapis, die beste resultate toon. 'n Verdere rede is dat die outistiese kind blykbaar nie die vermoë besit om onder gewone omstandighede te leer nic. Operante kondisionering is al dikwels onbillik aangeval, maar die hoopvolle prognose en dis toepassingsgeleenthede wat dit bied, bchoort as aansporing te dien om hierdic opvattings uit die weg te ruim.

\section{References}

1. Bettelheim: B. (1967): The Empty Fortress. Collier-Macmillan, London.

2. Brawley, E. R., Harris, F. R., Allen, H. K. E., Fleming, R. S. and Peterson, R. F. (1969): Behaviour modification of an autistic child. Behavioural Science, $14,87-97$.

3. Carrol, Lewis: Through the Looking Glass (1950): Max Parrish and Co., London.

4. Davis, B. J. (1968): A clinical method of appraisal of the langnage and learning behaviour of young antistic children. Journal of Communication Disorders, $1,277-296$.

5. Dubnoff, B. (1965): The habilitation and education of the allistic child in a therapentic day school. American Journal of Orthopsychiatry, 35 , $385-386$.

6. Fay, W. H. (1969): On the basis of allistic echolalia. Jounal of Communication Disorders, 2, 38-47.

7. Hermelin, B. (1966): Psychological Research. Early Childhood Autism, (Ed.) J. K. Wing. Pergammon Press, Oxford.

8. Hermelin, B. (1967): Coding and immediate recall in antistic children. Prcceedings of the Royal Society of Medicine. 60, 563-564.

9. Hermelin, B. and OCOnnor. N. (1964): Visual imperception, in psychotic children. British Journal of Psychology, 56, 455-460.

10. Hewett. F. M. (1965): Teaching speech 10 an antistic child through operant conditioning. American Journal of Orthopsychiatry, 35, 927-936.

11. Hingtgen, J. N and Churchill, D. W. (in press): Differential effects of behoviour modification in four mute autistic boys.

12. Hingtgen, J. N., Coulter, S. K. and Churchill, D. W. (1967): Intensive reinforcement of imitative behaviour in mute autistic children. Archives of General Psychiatry, 17, 36-43.

13. Hingtgen, J. N. and Trost, F. C. (1964): Shaping co-operative responses in carly childhood schizophrenics: II Reinforcement of mutual physical contact and vocal responses. Presented at' American Psychological Association.

Journal of the South African Logopedic Society, Vol. 16, No. I, Dec. 1969 
14. Jensen. G. D. and Womack, M. G. (1967): Operant conditioning techuiques applied in the treatment of an antistic child. American Journal of Orthopsychiatry, 37, 30-34.

15. Kanner. L. (1943): Amistic disturbances of affective contact. Nervous Child, 2, 217-250.

16. Kanner, L. and Eisenberg, L. (1955): Notes on the follow-up studies of antistic children. Psychopathology of Childhood: (Eds.) P. H. Hoch \& J. Zubin. Grune and Stratton, New York.

17. Leff, R. (1968): Behaviour modification and the psychoses of childhood: a revicw. Psychological Bulletin, 69, 396-409.

18. Lovaas, 1. (1966): A Program for the establishment of speech in prychotic children. Early Childhood Autism, (Ed.) J. K. Wing, Pergammon Press, Oxford.

19. Lovaas, I., Freitas, L., Nelson. K. \& Whalen, C. (1967): The establistmient of imitation and its use for the development of comples belaviour in schizophrenic children. Behaviour Research and Therapy, 5, 171-181.

20. O'Connor, N. and Hermelin, B. (1965): Sensory dominance in alutistic. children and controls. Archives of General Psychiatry. 12, 99-103.

21. Ornitz, E. M. and Ritvo, E. R. (1968a): Perceptnal inconstancy in early infontile antism. Archives of General Psychiatry, 18, 76-98.

22. Ornitz, E. M. and Ritvo. E. R. (1968b): Neurophysiologic mechanisms underlying perceptual inconstancy in anistic and schizophenic children. Archives of General Psychiatry, 19, 22-27.

23. Rimland. B. (1964): Infantile antism. Methuen, London.

24. Rimland, B. (1965): Breakthough in the treatment of menally ill childrent. Reprint of a lecture.

25. Risley, T. R. and Wolf, M. M. (1964): Experimental manipulation of antistic behaviours and generalisation into the home. Child Development: Readings in Experimental Analysis, (Eds. S. W. Bijou and D. M. Baer). Appleton-Century-Crofts, New York.

26. Risley, J. and Wolf M. (1967): Establishing functional speech in echolalic children. Bchaviour Research and Therapy. 5, 73-88.

27. Rityo, E. R.: Ornitz, E. M. and Franchi, S. (1968): Frequency of repetitive behaviours in early infantile antism and its variants. Archives of General Psychiatry, 19, 341-347.

28. Rutter, M. (1966: Behavionral and congnitive characteristics. Early Childhood Autism (Ed.) J. K. Wing. Pergammon Press, Oxford.

29. Rutter, M. (1968): Concepts of Atrism: "review of research. Journal of Child Psychology and Psychiatry, 9, 1-25.

30. Rutter, M., Greenfeld, D. and Lockyer. L. (1967): A five-year to fifteen year follow-up study of infantile psychosis. II Social and behavioural outcone. The British Journal of Psychiatry, 113, 1]83-1199.

31. Savage, V. A. (1968): Childhood antism: a review of the litcrature with particular reference to the speech and language structure of the autistic cliild. British Journal of Disorders of Communication, 3, 75-87.

32. Schell, R. E., Stark, J. and Giddon, J. J. (1967): Development of language behaviour in an autistic child. Journal of Speech and Hearing Disorders, $32,51-64$.

33. Sorosky, A. D., Ornitz, E. M., Brown, M. B. and Ritvo, E. R. (1968): Systematic observations of autistic behaviour. Archives of General Psychiatly, 18, 439-449.

34. Stark, J.: Giddan, J. J. and Meisel. J. (1968): Increasing verbal behaviour in an antistic child. Journal of Speech and I Hearing Disorders, 33, 42-47.

35. Weiland, I. H. and Rudnik, R. (1961): Considerations of the development and treatment of antistic childhood psychosis. The Psychoanalytic Study of the Child, 16. 549-563.

36. Wolf, M., Risley, T. R. and Mees, H. (i964): Application of operant conditioning procedures to the behaviour problems of an antistic child. Behaviour Research and Therapy, 1, 305-312. 